\title{
Farklı Beden Kütle İndeksi Değerine Sahip Yetişkin Kadınların Sosyo-demografik Özellikleri ile Yeme Tutumlarının Değerlendirilmesi
}

\author{
Sociodemographic Characteristics and Eating Attitudes Among Adult Women with Different \\ Body Mass Index Levels
}

\author{
Nurbanu Öztayıncı ${ }^{1}$ Aylin Açıkgöz Pınar², Emine Akal Yıldız³ , Hülya Gökmen Özel ${ }^{4}$
}

Geliş tarihi/Received: 27.09.2021 • Kabul tarihi/Accepted: 27.12.2021

\section{ÖZET}

Bu çalışma Ankara'da bulunan bir Aile Sağlığı Merkezi’ne başvuran beden kütle indeksi (BKi) farklı 19-64 yaş aralığında ki 155 kadının beslenme durumunu ve yeme tutumunu değerlendirmek amacıyla yapılmıştır. Kadınların genel özellikleri, uyku süreleri sorgulanmış, antropometrik ölçümleri alınmıştır. Ayrıca bireylerin yeme tutum ve davranışlarını değerlendirmek için Yeme Tutum Testi-40 (YTT-40) skoru hesaplanmıştır. Her BKİ sınıflamasından homojen sayıda birey alınarak, sonuçlar 3 gruba (zayıf ve normal, fazla kilolu ve obez) göre incelenmiştir. Zayıf ve normal BKİ grubundaki bireylerin \%61.6'sı 19-34 yaş aralığındayken, fazla kilolu grubundaki bireylerin \%64.7’si 45-64 yaş aralığında, obez bireylerin ise \%77.0'ı 45-64 yaş aralı̆̆ındadır $(\mathrm{p}<0.05)$. Eğitim süresi ortalaması zayıf ve normal BKİ’ndeki bireylerin $13.7 \pm 3.36$ yll, fazla kilolu bireylerin 11.5 \pm 4.31 yll ve obez bireylerin ise 8.0 \pm 3.85 yll olarak bulunmuştur $(\mathrm{p}<0.05)$. Üzüntü, öfke ve stres anlarında; obez bireylerde iştah durumunda artma, diğer gruplardaki bireylere göre anlamlı bir şekilde daha fazla görülmüştür ( $<<0.05)$. Yeme tutum testi skoru ortalaması zayıf ve normal bireylerde $16.8 \pm 8.59$, hafif şişman bireylerde $19.7 \pm 8.35$, obez bireylerde $22.8 \pm 8.8$ puan olarak bulunmuştur. Obez bireylerde anormal yeme davranışı diğer gruplara göre daha fazla görülebileceğinden, içinde doktor, diyetisyen ve psikoloğun da bulunacağı interdisipliner bir yaklaşım modeli örnek alınarak, bireylerin sağlıklı yaşam tarzı alışkanlıkları kazanmasına yardımcı olunmalıdır.

Anahtar kelimeler: Beslenme durumu, sosyo-demografik özellikler, yeme tutumu, obezite

\begin{abstract}
This study was conducted on evaluating the relation between nutritional status and eating attitudes in 155 women with different body mass index (BMI) levels aged from 19 to 64 who were admitted to a Family Health Center in Ankara. The general characteristics and sleep duration of the women were questioned, and the anthropometric measurements were taken. Additionally, eating attitudes test (EAT-40) scores were calculated to determine eating attitudes and behaviors. The results were examined according to three BMI levels, including participants for each BMI level homogeneously. In this study; $61.6 \%$ of underweight and normal-weight women were at the age range from 19 to $34,64.7 \%$ of overweight women,
\end{abstract}

Bu çalışma, Dyt. Nurbanu Öztayınc’’nın Hacettepe Üniversitesi Sağlık Bilimleri Enstitüsü’nde 24 Eylül 2019 tarihinde kabul edilen yüksek lisans tezinden üretilmiştir.

1. İletişim/Correspondence: Kağıthane İlçe Sağlık Müdürlüğü, Sağlıklı Beslenme ve Obezite Danışma Birimi, İstanbul, Türkiye

E-posta: nurbanu.oztayinci@saglik.gov.tr • @ https://orcid.org/0000-0003-3455-7571

2. Hacettepe Üniversitesi, Sağllk Bilimleri Fakültesi, Beslenme ve Diyetetik Bölümü, Ankara, Türkiye • 으 https://orcid.org/0000-0002-8847-9305
3. Doğu Akdeniz Üniversitesi, Sağlık Bilimleri Fakültesi, Beslenme ve Diyetetik Bölümü, Gazimağusa, KKTC • ๑ https://orcid.org/0000-0002-1144-5641

4. Hacettepe Üniversitesi, Sağlık Bilimleri Fakültesi, Beslenme ve Diyetetik Bölümü, Ankara, Türkiye - ๑ https://orcid.org/0000-0002-8282-6468 
and $77.0 \%$ of obese women were at the age range from 45 to $64(\mathrm{p}<0.05)$. The mean of education period was $13.7 \pm 3.36$ years for underweight and normal-weight women, 11.5 \pm 4.31 years for overweight women, and 8.0 \pm 3.85 years for obese women $(\mathrm{p}<0.05)$. At the point of sadness, rage, and stress; increased appetite was seen significantly in obese individuals compared with the others $(\mathrm{p}<0.05)$. The mean EAT-40 scores for underweight and normal-weight women were 16.8 \pm 8.59 ; $19.7 \pm 8.35$ for overweight women and $22.8 \pm 8.8$ for obese women. Since abnormal eating behavior can be seen more in obese individuals than in other groups, an interdisciplinary approach model that includes medical doctors, dietitians and psychologists should be taken as an example, and individuals should be helped to gain healthy lifestyle habits.

Keywords: Nutritional status, sociodemographic characteristics, eating attitude, obesity

\section{GíRiş}

Obezite, vücut yağ kütlesinin yağsız kütleye oranla artması sonucunda, boy uzunluğuna göre vücut ağırlığının olması gereken düzeyin üzerinde olması durumu şeklinde tanımlanabilmektedir (1). Dünya Sağlık Örgütü (DSÖ) tarafından ise vücutta sağlığı bozabilecek ölçüde anormal veya aşırı miktarda yağ birikimi olarak tanımlanmıştır (2).

Obezite prevalansının DSÖ’nün verilerine göre; 1975 yılı sonrası yaklaşık 3 katına çıktığı bildirilmektedir. Yetişkin bireyler arasında 2016 yllında 650 milyondan fazla bireyin obez olduğu DSÖ tarafından belirtilmiştir. Dünya genelinde yetişkin popülasyonun, 2016 yılı itibari ile yaklaşık \%13’ünün (\%11 erkek ve \%15 kadın) obez olduğu belirtilmiştir (2). Türkiye Beslenme ve Sağlık Araştırması-2017 (TBSA-2017) verilerine göre ise, 19-64 yaş arası bireylerin \%32.1'inin beden kütle indeksi (BKİ) değerlerinin $30 \mathrm{~kg} / \mathrm{m}^{2}$ ve üzeri olduğu saptanmıştır (3).

Obezite, genetik ve çevresel etkileşimleri olan ciddi, kronik bir hastalıktır ve diyabet, hipertansiyon, kalp-damar hastalıkları gibi kronik hastalıklara yol açabilmektedir (4). Fazla kilolu olma ve obezite, alınan enerji miktarının, harcanan enerji miktarından fazla olduğu durumlarda gelişmektedir. Bu tür bir enerji dengesizliği vücutta yağ depolanmasına neden olmaktadır (5). Benzer şekilde yaş ile birlikte metabolik hız ve enerji harcaması azalmakta ve enerji alımı bu süreçte dengelenmezse vücut ağırlığı artışı ile karşılaşılmaktadır (6).
Son ylllarda teknolojinin de hayatımıza girmesiyle birlikte giderek artan sedanter yaşam tarzının yanı sıra yetersiz uyku süresi ve kalıtım gibi etmenler de obezitenin nedenleri arasında gösterilmektedir (7-9). Öğün atlama, öğün aralarında enerji içeriği yüksek besinlerin atıştırılması, şekerle tatlandırılmış içeceklerin tüketilmesi, ev dışında tüketilen öğün sıklığının artması ve duygusal yeme gibi sağlıksız beslenme alışkanlıkları da obezitenin nedenleri arasında sayılmaktadır (10).

Duygusal yeme, kaygı ve sinirlilik gibi negatif duygulara yanıt olarak aşırı yemeye eğilim olarak tanımlanabilmektedir (11). Otuz üç çalışmanın incelendiği bir meta-analizde olumsuz duygularm (öfke, üzüntü, stres, kaygı veya korku) daha fazla besin alımına yol açtığı bildirilmiştir (12). Olumsuz durumlar karşısında besin alımındaki artış durumunun daha çok obez, diyet uygulayan ve yeme bozukluğu olan bireylerde gözlemlendiği belirtilmiştir (13).

Yeme tutumu, besinlere karşı gösterilen inanç, düşünce ve duygular olarak tanımlanabilmekte ve besinlerle olan ilişkimizi ifade etmektedir. Biyolojik, genetik, psikolojik ve ailesel etmenler ile sosyokültürel çevre, yeme tutumunu etkilemektedir. Bazı çalışmalarda BKİ ile yeme tutumu arasında ilişki saptanmıştır $(14,15)$.

$\mathrm{Bu}$ çalışma farklı BKİ değerlerine sahip yetişkin kadınların, beslenme durumları ile yeme tutumlarının değerlendirilmesi amacıyla planlanmış ve yürütülmüştür. 


\section{BIREYLER VE YÖNTEM}

\section{Araştırma Yeri, Zamanı ve Örneklem Seçimi}

Araştırma, Haziran-Temmuz 2016 tarihleri arasında Ankara ilindeki bir Aile Sağllğı Merkezi’ne başvuran yaşları 19-64 yıl arasında değişen farklı BKİ değerlerine sahip 155 gönüllü yetişkin kadının katılımı ile gerçekleştirilmiştir. Üç farklı BKİ sınıfından (zayıf+normal, fazla kilolu ve obez) homojen sayıda bireyin katılımina dikkat edilerek, zayıf ve normal BKİ değerlerine sahip 52, fazla kilolu 51, obez 52 kadın çalışmaya dahil edilmiştir. Gebe ve emzikli kadınlar araştırmaya dahil edilmemiştir. Ankara'da yaşayan 19-64 yaş arası kadınlar çalışmanın evrenini oluşturmaktadır. Çalışmaya başlamadanönce 0.05 hata payı ve $\% 80$ güç alınarak en az 150 kişinin çalışmaya katılması gerektiği belirlenmiştir. Rastgele örneklem seçimi yapılarak 155 kadın çalışmaya katılmıştır. Beden kütle indeksi değerleri DSÖ sınıflamasına göre değerlendirilmiştir (2). Buna göre BKİ $<18.5 \mathrm{~kg} / \mathrm{m}^{2}$ olanlar zayıf, BKİ $18.5-24.99 \mathrm{~kg} / \mathrm{m}^{2}$ arasında olanlar normal, $25.0-29.99 \mathrm{~kg} / \mathrm{m}^{2}$ arasinda olanlar fazla kilolu, $\geq 30 \mathrm{~kg} / \mathrm{m}^{2}$ olanlar obez olarak tanımlanmıştır. Çalışma, Hacettepe Üniversitesi Girişimsel Olmayan Klinik Araştırmalar Etik Kurulu'nun 10.05.2016 tarihli ve GO 16/294 sayılı onayı ile gerçekleştirilmiştir.

\section{Verilerin Toplanması}

Bireylerin sosyo-demografik özellikleri, uyku süresi ve duygusal durumlarına göre iştah durumlarını içeren anket formu yüz yüze görüşme yöntemiyle alınmıştır. Vücut ağırlığı (kg), boy uzunluğu (cm), bel ve kalça çevresi ölçümleri (cm) gibi bazı antropometrik ölçümler alınmıştır. Vücut ağırlığı, ayakkabısız olarak dijital terazi ile ölçülmüştür. Boy uzunluğu ölçümü yapılırken başın frankfort düzlemde olmasına dikkat edilmiştir. Beden kütle indeksi (BKİ), vücut ağırlığı $(\mathrm{kg}) /$ boy $\left(\mathrm{m}^{2}\right)$ formülünden hesaplanmıştır (16). Bireylere aydınlatılmış onam formu imzalatılmıştır.

\section{Yeme Tutumu Testi}

Çalışma kapsamındaki bireylerin yeme tutumlarının değerlendirilmesinde, Yeme Tutum Testi (YTT-40) kullanılmıştır (17). Yeme tutumu testi, anoreksiya nervoza tanılı bireylerin yeme davranışlarını/ tutumlarını ve normal bireylerde var olan, olası yeme tutumu bozukluklarını araştırmak amacıyla kullanılan, Garner ve Görfinkel (18) tarafından geliştirilmiş ve Türkçeye uyarlanarak geçerlik ve güvenirlik çalışması yapılmış bir testtir (17). Yeme tutum testinin kesim puanı 30 olarak saptanmıştır. Otuz üzerinde alınan toplam puan anormal yeme davranışı olarak belirtilmiştir (18).

\section{Verilerin İstatistiksel Değerlendirmesi}

Çalışmada elde edilen bulgular değerlendirilirken, istatistiksel analizler için Sosyal Bilimler için İstatistik Paket Programı- SPSS 22.0 (SPSS, Armonk, New York) programı kullanılmıştır (19). Çalışma verileri değerlendirilirken parametrelerin normal dağılıma uygunluğuincelenirkenShapiroWilkstesti,tanımlayıcı istatistiksel metodların (Ortalama, Standart sapma, frekans) ve niceliksel verilerin karşılaştırılmasında normal dağılım gösteren parametrelerin gruplar arası karşılaştırmalarında Oneway Anova testi uygulanmıştır. Normal dağılım göstermeyen parametrelerin gruplar arası karşılaştırmalarında Kruskal Wallis testi kullanılmıştır. İki grup arası karşllaştırmalarda Student t testi, niteliksel verilerin karşılaştırılmasında Ki Kare test uygulanmıştır. Verilerin değerlendirilmesinde tanımlayıcı istatistiklerden ortalama, ortanca, standart sapma, minimum ve maksimum değerler ile sayı ve yüzdeler kullanılmıştır. Tüm istatistiksel analizlerde hata payı $\mathrm{p}<0.05$ olarak kabul edilmiştir.

\section{BULGULAR}

Bireylere ait genel özellikler Tablo 1'de verilmiştir. Yaş ortalamaları, zayıf ve normal BKI değerlerine sahip bireylerin $32.8 \pm 10.88$ yll, fazla kilolu bireylerin $45.9 \pm 12.74$ yll, obez bireylerin $50.8 \pm 9.67$ yldır. Zayıf ve normal BKİ değerlerine sahip bireylerin 19-24 yaş aralığında ve 25-34 yaş aralığında olma sıklıkları, fazla kilolu ve obez bireylerden istatistiksel olarak anlamlı düzeyde yüksektir ( $\mathrm{p}=0.001$ ) (Tablo 1). 
Tablo 1. Bireylerin BKİ sınıflamasına göre yaş, eğitim durumu, eğitim süresi, meslek ve medeni durum parametrelerinin değerlendirilmesi

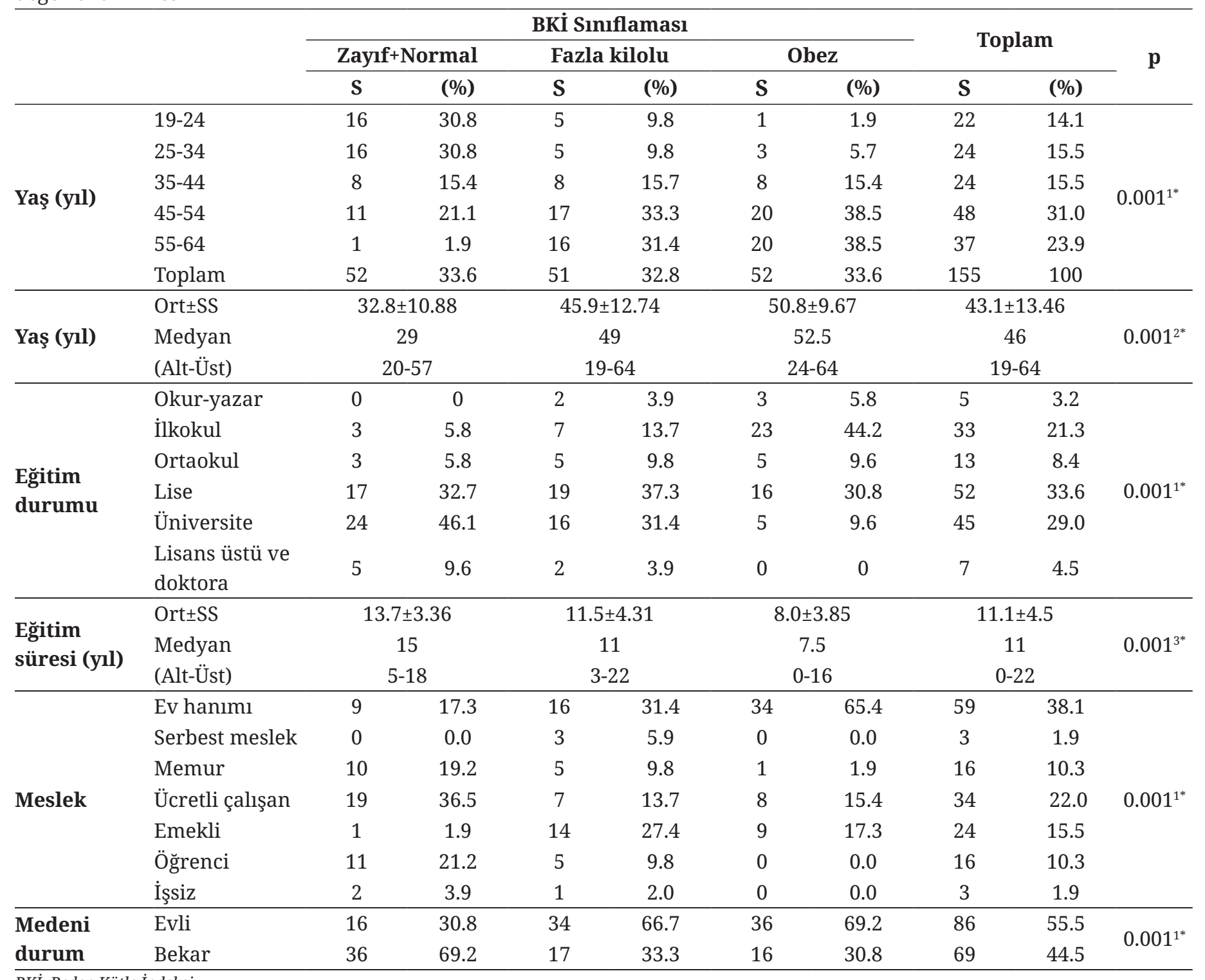

BKİ: Beden Kütle İndeksi

${ }^{1}$ Ki Kare Test ${ }^{2}$ Kruskal Wallis Test ${ }^{3}$ One way Anova Test ${ }^{*} p<0.05$

Obez bireylerin ilkokul mezunu olma sıklığı, zayıf ve normal $(p=0.001)$ BKİ değerlerine sahip ve fazla kilolu ( $(p=0.002)$ bireylerden istatistiksel olarak anlamlı düzeyde yüksek olduğu görülmüştür ( $p<0.05)$. Zayıf ve normal BKİ değerlerine sahip bireylerin eğitim süresi ortalaması $13.7 \pm 3.36$ yıl, hafif şişman bireylerin 11.5 \pm 4.31 yll, obez bireylerin 8.0 \pm 3.85

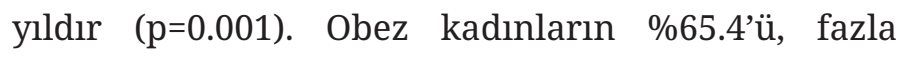
kilolu grubunun \%31.4’ü, zayıf ve normal grubunun \%17.3’ü ev hanımıdır. Obez grubundaki bireylerin ev hanımı olma sıklığı, zayıf ve normal ve fazla kilolu gruplarından istatistiksel olarak anlamlı düzeyde yüksektir ( $\mathrm{p=0.001)}$ (Tablo 1).

Zaylf ve normal BKİ değerlerine sahip bireylerin bulunduğu grubun \%69.2'si bekardır. Fazla kilolu bireylerin \%66.7'si, obez bireylerin \%69.2'si evlidir $(p=0.001)$. Zaylf ve normal BKİ değerlerine sahip bireylerin bekar olma sıklığl, hafif şişman ve obez bireylerden istatistiksel olarak anlamlı düzeyde yüksektir ( $\mathrm{p}=0.001)$ (Tablo 1). 
Bireylerin günlük ortalama uyku süreleri karşılaştırıldığında, zayıf ve normal BKİ değerlerine sahip bireylerin \%78.8'i 7 saat ve üzerinde uyurken, fazla kilolu bireylerde bu sıklık \%70.6’ya, obez bireylerde \%50.0’a düşmüştür $(\mathrm{p}=0.006)$. Zayıf ve normal BKİ değerlerine sahip bireylerde 7 saat ve üzerinde uyuma sıklığı, obez bireylerden istatistiksel olarak anlamlı düzeyde yüksektir ( $\mathrm{p}=0.004)$ (Tablo 2).

Bireylerin duygusal durumlarına göre iştah durumları BKİ sınıflandırmasına göre değerlendirildiğinde, üzgün iken, zayıf ve normal BKİ değerlerine sahip bireylerin \%13.5’i, fazla kilolu bireylerin \%25.5’i, obez bireylerin \%46.2'si iştahının arttığını belirtmiştir ve aradaki fark anlamlıdır ( $\mathrm{p}=0.003)$. Obez bireylerin üzgünken iştahının artma sıklığı, zayıf ve normal $(\mathrm{p}=0.001)$ BKİ değerlerine sahip ve fazla kilolu $(p=0.042)$ bireylerden istatistiksel olarak anlamlı düzeyde yüksektir $(\mathrm{p}<0.05)$. Öfkeli iken, zayıf ve normal BKİ değerlerine sahip bireylerin \%13.5'i, fazla kilolu bireylerin \%23.5'i, obez bireylerin \%53.9'u iştahının arttığını belirtmiştir ( $\mathrm{p}=0.001)$. Obez bireylerin öfkeliyken iştahının artma sıklığı, zayıf ve normal ( $p=0.001$ ) BKİ değerlerine sahip ve fazla kilolu $(p=0.006)$ bireylerden istatistiksel olarak anlamlı düzeyde daha yüksektir $(\mathrm{p}<0.05)$. Stresli iken, zayıf ve normal BKİ değerlerine sahip bireylerin \%19.2'si, fazla kilolu bireylerin \%33.3'ü, obez bireylerin \%59.6'sı iştahının arttığını belirtmiştir ve aradaki fark anlamlıdır ( $\mathrm{p}=0.001)$. Obez bireylerin stresliyken iştahının artma sıklığı, zayıf ve normal $(\mathrm{p}=0.001)$ BKI değerlerine sahip ve fazla kilolu $(\mathrm{p}=0.028)$ bireylerden istatistiksel olarak anlamlı düzeyde yüksektir $(\mathrm{p}<0.05)$ (Tablo 3).

Zayıf ve normal BKİ değerlerine sahip bireylerin \%3.8'inin, fazla kilolu bireylerin \%11.8'inin, obez bireylerin \%23.5'inin YTT puanı 30 ve üzeridir $(p=0.012)$. Zayıf ve normal BKİ değerlerine sahip bireylerin YTT puanı 30 ve üzerinde olma sıklığı, obez bireylerden istatistiksel olarak anlamlı düzeyde düşüktür ( $p=0.009)$. Diğer gruplar arasında YTT puanı grupları dağılım sıklıkları açısından istatistiksel olarak anlamlı bir farklılık bulunmamaktadır $(\mathrm{p}>0.05)$ (Tablo 4).

Beden kütle indeksi arttıkça YTT puanlarında artış görülmektedir (sırasıyla; 16.8 $\pm 8.59,19.7 \pm 8.35$, $22.8 \pm 8.8, \mathrm{p}=0.001$ ). Zayıf ve normal BKİ değerlerine sahip bireylerin YTT puanı, fazla kilolu ve obez bireylerden istatistiksel olarak anlamlı düzeyde düşüktür $\left(\mathrm{p}_{1}=0.046 ; \mathrm{p}_{2}=0.000 ; \mathrm{p}<0.05\right)$. Fazla kilolu bireylerin YTT puanı da obez bireylerden istatistiksel olarak anlamlı düzeyde düşüktür $(\mathrm{p}=0.040 ; \mathrm{p}<0.05)$ (Tablo 5).

\section{TARTIŞMA}

Fazla kiloluluk ve obezite, tüm dünyada önemli bir halk sağlığı sorunu haline gelmiştir ve toplumun her kesiminde artış göstermektedir (2). Genetik ve beslenme alışkanlıklarının yanı sıra, ileri yaş, evli olma durumu, düşük gelir düzeyi, öğrenim durumu gibi sosyodemografik etmenlerin de obeziteyle ilişkisi bulunmaktadır (20). Yaşları 19-79 arası değişen Koreli kadınlar arasında yapılan bir çalışmada, daha genç yaş grubuyla karşılaştırıldığında 45-64 yaş arasındaki kadınların obez olma olasılığının daha yüksek olduğu belirtilmiştir (21). İran'da yapılan bir kohort çalışmasında bireyler obezite gelişimi açısından 8 yıl süreyle incelenmiştir. Bu süre boyunca kadınlarda obezitenin 40-49 yaşları arasında en yüksek sıklıkta ortaya çıktığı belirlenmiştir (22). Ülkemizde

Tablo 2. Beden kütle indeksi sınıflamasına göre uyku süresinin değerlendirilmesi

\begin{tabular}{|c|c|c|c|c|c|c|c|c|}
\hline \multirow{3}{*}{ Uyku saati } & \multicolumn{6}{|c|}{ BKİ Sınıflaması } & \multirow{2}{*}{\multicolumn{2}{|c|}{ Toplam }} \\
\hline & \multicolumn{2}{|c|}{ Zayıf+Normal } & \multicolumn{2}{|c|}{ Fazla kilolu } & \multicolumn{2}{|c|}{ Obez } & & \\
\hline & $\mathrm{S}$ & $(\%)$ & $\mathbf{S}$ & $(\%)$ & $\mathrm{S}$ & $(\%)$ & $S$ & $(\%)$ \\
\hline$<7$ saat & 11 & 21.2 & 15 & 29.4 & 26 & 50.0 & 52 & 33.5 \\
\hline$\geq 7$ saat & 41 & 78.8 & 36 & 70.6 & 26 & 50.0 & 103 & 66.5 \\
\hline
\end{tabular}

BKİ: Beden Kütle İndeksi

Ki Kare Test ${ }^{*} p<0.05$ 
Tablo 3. Beden kütle indeksi sınıflamaları göre bireylerin duygusal durumları ile iştah durumlarının değerlendirilmesi

\begin{tabular}{|c|c|c|c|c|c|c|c|c|}
\hline & \multicolumn{6}{|c|}{ BKİ Sınıflaması } & \multirow{2}{*}{\multicolumn{2}{|c|}{ Toplam }} \\
\hline & \multicolumn{2}{|c|}{ Zayıf+Normal } & \multicolumn{2}{|c|}{ Fazla kilolu } & \multicolumn{2}{|c|}{ Obez } & & \\
\hline & S & (\%) & $\mathbf{S}$ & (\%) & $\mathbf{S}$ & (\%) & $\mathbf{S}$ & (\%) \\
\hline \multicolumn{9}{|l|}{ Mutluyken } \\
\hline İştahım artar & 21 & 40.4 & 16 & 31.4 & 10 & 19.2 & 47 & 30.3 \\
\hline İştahım azalır & 10 & 19.2 & 7 & 13.7 & 14 & 26.9 & 31 & 20.0 \\
\hline İştahım değişmez & 21 & 40.4 & 28 & 54.9 & 28 & 53.9 & 77 & 49.7 \\
\hline \multicolumn{9}{|l|}{ Üzgünken } \\
\hline İştahım artar & 7 & 13.5 & 13 & 25.5 & 24 & 46.2 & 44 & 28.4 \\
\hline İştahım azalır & 35 & 67.3 & 26 & 51.0 & 23 & 44.2 & 84 & 54.2 \\
\hline İştahım değişmez & 10 & 19.2 & 12 & 23.5 & 5 & 9.6 & 27 & 17.4 \\
\hline \multicolumn{9}{|l|}{ Heyecanliyken } \\
\hline İştahım artar & 9 & 17.3 & 4 & 7.8 & 3 & 5.8 & 16 & 10.3 \\
\hline İştahım azalır & 24 & 46.2 & 29 & 56.9 & 34 & 65.4 & 87 & 56.1 \\
\hline İştahım değişmez & 19 & 36.5 & 18 & 35.3 & 15 & 28.8 & 52 & 33.6 \\
\hline \multicolumn{9}{|l|}{ Endişeliyken } \\
\hline İştahım artar & 7 & 13.5 & 4 & 7.8 & 6 & 11.5 & 17 & 10.9 \\
\hline İştahım azalır & 33 & 63.5 & 32 & 62.8 & 34 & 65.4 & 99 & 63.9 \\
\hline İştahım değişmez & 12 & 23.0 & 15 & 29.4 & 12 & 23.1 & 39 & 25.2 \\
\hline \multicolumn{9}{|l|}{ Öfkeliyken } \\
\hline İştahım artar & 7 & 13.5 & 12 & 23.5 & 28 & 53.9 & 47 & 30.3 \\
\hline İştahım azalır & 32 & 61.5 & 25 & 49.0 & 14 & 26.9 & 71 & 45.8 \\
\hline İştahım değişmez & 13 & 25.0 & 14 & 27.5 & 10 & 19.2 & 37 & 23.9 \\
\hline \multicolumn{9}{|l|}{ Stresliyken } \\
\hline İştahım artar & 10 & 19.2 & 17 & 33.3 & 31 & 59.6 & 58 & 37.4 \\
\hline İştahım azalır & 30 & 57.7 & 23 & 45.1 & 14 & 26.9 & 67 & 43.2 \\
\hline İştahım değişmez & 12 & 23.1 & 11 & 21.6 & 7 & 13.5 & 30 & 19.4 \\
\hline
\end{tabular}

BKİ: Beden Kütle İndeksi

Ki Kare Test ${ }^{*} p<0.05$

Tablo 4. Beden kütle indeksi sınıflamasına göre YTT puanı değerlendirilmesi.

\begin{tabular}{lcccccccc}
\hline & \multicolumn{9}{c}{ BKİ Sinıflaması } & \multicolumn{2}{c}{ Toplam } \\
\cline { 2 - 8 } YTT puanı & \multicolumn{2}{c}{ Zayıf+Normal } & \multicolumn{2}{c}{ Fazla kilolu } & Obez & S \\
\cline { 2 - 9 } & $\mathbf{S}$ & $\mathbf{( \% )}$ & $\mathbf{S}$ & $\mathbf{( \% )}$ & $\mathbf{S}$ & $\mathbf{( \% )}$ & $\mathbf{( \% )}$ \\
\hline$<\mathbf{3 0}$ & 50 & 96.2 & 45 & 88.2 & 39 & 76.5 & 134 \\
$\geq \mathbf{3 0}$ & 2 & 3.8 & 6 & 11.8 & 12 & 23.5 & 20 & 13.0 \\
\hline
\end{tabular}

BKİ: Beden Kütle İndeksi, YTT: Yeme Tutum Testi

Ki Kare Test ${ }^{*} p<0.05$

Tablo 5. Beden kütle indeksi sınıflamalarına göre yeme tutum testi puanlarının ortalama, standart sapma, medyan ve alt-üst değerleri

\begin{tabular}{lccc}
\hline \multirow{2}{*}{ BKI Sinıflaması } & \multicolumn{3}{c}{ YTT puanı } \\
\cline { 2 - 4 } & Ort \pm SS & Medyan & Alt-üst \\
\hline Zayıf+Normal & $16.8 \pm 8.59$ & 16 & $4-47$ \\
Fazla kilolu & $19.7 \pm 8.35$ & 17 & $7-50$ \\
Obez & $22.8 \pm 8.8$ & 24 & $7-41$ \\
Toplam & $19.8 \pm 8.87$ & 18 & $4-50$ \\
\hline
\end{tabular}

BKİ: Beden Kütle İndeksi, YTT: Yeme Tutum Testi

Kruskal Wallis Test ${ }^{*} p<0.05$ 
yapılan bir çalışmada artan yaş ile obezite ilişkili bulunmuştur. Obezite sıklığının 30 yaşından sonra artmaya başladığı, 40-44 yaş grubunda ise en yüksek sıklıkta görüldüğü bildirilmiştir (23). Bu çalışma da diğer çalışmalardaki bulguları destekler niteliktedir. Beden kütle indeksi arttıkça bireylerin 45-54 ve 55-64 yaş gruplarında bulunma sıklığı yükselmiştir. Yaşla birlikte bazal metabolizma hızının azalması ve fiziksel aktivite düzeyinin azalmasına bağlı olarak enerji harcamasının azalması bu durumu etkileyebilir. Öğünlerin düzensiz olması, sebze-meyve ve tam tahıllılar gibi posalı besinlerin tüketiminin azalması, şekerli ve yağlı yiyeceklerin tüketimin artması bu durumun nedenleri arasında gösterilebilir.

Farklı ülkelerde yapılan çalışmalarda eğitim düzeyi ile BKİ arasında ters bir ilişki bulunmuştur (21-24). Brezilya'da yapılan bir çalışmada eğitim düzeyi yüksek yerlerde yaşayan kadınlarla karşılaştırıldığında, eğitim düzeyi düşük yerlerde yaşayan kadınların BKİ değerlerinin $1.12 \mathrm{~kg} / \mathrm{m}^{2}$ daha fazla olduğu belirtilmiştir (24). Başka bir çalışmada ortaokul ve altı eğitim düzeyi olan kadınlarda obezitenin daha yüksek olduğu belirtilmiştir. Eğitim düzeyi yükseldikçe bu olasılığın azaldığı bildirilmiştir (21). Bu çalışmada da eğitim durumu arttıkça obezite sıklığının azaldığı görülmüştür. Eğitim düzeyinin artmasıyla bireyin maddi durumunun da yükselerek, yeterli ve dengeli beslenme olanağını arttıracağı, yaşadığı çevreyi ve stres düzeyini etkileyeceği düşünülebilir. Fiziksel aktivite ve egzersiz yapma imkânı sunan bir çevrede yaşamak bireylerde obez olma olasılığını azaltıcı bir etki gösterebilir.

Yapılan çalışmalarda medeni durum obeziteyle ilişkili bulunmuştur (25-28). Bu çalışmada da obez ve fazla kilolu bireylerin çoğunluğunun evli, zayıf ve normal BKİ değerlerine sahip bireylerin ise çoğunluğunun bekar olduğu bilgisine ulaşılmıştır. Benzer şekilde, Avrupa'da 9 ülkenin verilerinin kullanıldığı bir araştırmada hiç evlenmeyen bireylerin BKI değerlerinin, evli bireylerinkinden daha düşük olduğu belirtilmiştir (27). Bu ilişki, bireylerin evlilik sonrası dengesiz beslenme ve hareketsiz yaşam tarzını benimsemesi ve kadınların gebelik sürecinde yaşadıkları vücut ağırlığı artışı sonrası alışılmış vücut ağırlıklarına geri dönememelerinden kaynaklanıyor olabilir. Yemeklerde porsiyonun artması, verilen davetlerde tatlı ve hamur işi gibi enerji yoğunluğu yüksek yiyeceklerin tüketiminin artması bu durumu etkileyebilir. Evlilik sonrası stres kaynaklarının çoğalması da obez olma riskini arttırabilir.

İran'da yapılan bir çalışmada ev kadınlarının \%42.5'inin obez olduğu ve obezitenin oluşumunda ev kadınlarının büyük bir risk taşıdığı vurgulanmıştır (29). Ankara'da yaşayan kadınlar arasında yapılan bir çalışmada ev kadınlarının çalışan kadınlara göre 6.5 kat daha fazla obezite riski taşıdıkları belirtilmiştir (30). Bu çalışmada da 3 grup arasında ev kadını olma sıklığı en yüksek olan grup obez grubudur. Bu durum ev kadınlarının kendi aralarında yaptığı toplantılarda daha çok hamur işi, pasta vb. sağlıksız seçenekleri tüketmeleri ile TV karşısında geçen zamanın artması ile sedanter yaşam tarzını benimsemelerinden kaynaklanıyor olabilir.

Yapılan bir çalışmada günde 6 saatten az uyuyan bireylerin, günde 7-8 saat uyuyanlarla karşılaştırıldığında BKİ değerlerinin $1.3 \pm 0.7 \mathrm{~kg} /$ $\mathrm{m}^{2}$ daha fazla olduğu ve bu ilişkinin kadınlarda daha belirgin olduğu belirtilmiştir (31). Bir başka araştırmada duygusal stresin, uyku süresi ile obezite arasındaki ilişkiyi dolaylı olarak etkileyebileceğine dikkat çekilmiştir (32). Yapılan bir kohort çalışmasında 7-8 saat uyuyanlarla karşılaştırıldığında 6 saatten az uyku, daha fazla ağırlık kazanımıyla ilişkili bulunmuştur (33). Bu çalışmada da BKİ arttıkça 7 saatten az uyuma sıklığının arttığı görülmüştür.

$\mathrm{Bu}$ çalışmada BKİ arttıkça üzüntü, öfke ve stres durumlarında iştah artışıyla karşılaşma sıklığı yükselmiştir. İstanbul'da obez kadınlar arasında yapılan bir çalışmada, üzüntülü ve sıkıntılı durumlarda daha çok yemek yendiği belirlenmiştir (34). Başka bir araştırmada da, obez kadınlarda üzüntü, yorgunluk ve sevinç gibi duygu durumlarında iştahın arttığı bulunmuştur (35). Duygusal yemenin obezitenin nedenleri arasında olabileceği ve günümüzde artmış stresin obezite için bir risk etmeni 
olabileceği düşünülebilir. Bu çalışmada örneklem sayısı az olduğu için, daha fazla bireyin katılımıyla gerçekleşecek çalışmalar daha kapsamlı olacaktır.

Bu çalışmada BKİ arttıkça YTT-40 puanı artmıştır. Türkiye’de 525 üniversite öğrencisi arasında yürütülen bir çalışmada BKİ değeri normal aralıkta olan bireylerin \%12.3'ünün, fazla kilolu/obez olanların \%23.7'sinin YTT-40 puanı 30'un üzerinde bulunmuştur. Farklar istatistiksel olarak anlamlıdır. Yeme bozukluğu riskinin fazla kilolu/obez olanlarda, normal BKİ aralığında olanlara göre 2 kat daha fazla olduğu bildirilmiştir (15). Başka bir çalışmada, normal BKİ değerlerine sahip olan kadınların YTT puanı ortalaması $18.81 \pm 8.27$ iken, obez kadınlarda $21.67 \pm 10.58$ 'e yükseldiği ve farkın anlamlı olduğu bulunmuştur. Aynı çalışmada normal BKİ değerlerine sahip olan kadınların \%9.1'inde yeme davranış bozukluğu tespit edilmiş olup, obez kadınlarda bu sıklık \%17.5 olarak belirtilmiştir (36). Başka bir çalışmada kadınların YTT-40 puan ortalaması 20.2 \pm 7.9 olup, 61 kadının 8'inde anormal yeme davranışına rastlanmıştır. Anormal yeme davranışı olanların BKİ ortalaması $27.8 \pm 5.3 \mathrm{~kg} / \mathrm{m}^{2}$ iken, yeme davranış bozukluğu olmayanların ortalaması $25.2 \pm 4.9 \mathrm{~kg} / \mathrm{m}^{2}$ olarak tespit edilmiş ve aralarındaki fark anlamlı bulunmamıştır (37). İstanbul'da yapılan bir çalışmada da fazla kilolu ve obez bireylerin YTT puanlarının daha yüksek olduğu görülmüştür (38). Başka bir çalışmada ise anormal yeme davranışı olan bireylerin BKİ değerleri daha yüksek bulunmuştur (39). Benzer bir şekilde Mısır'da yapılan bir çalışmada da obez bireylerde anormal yeme davranışının daha fazla görüldüğü saptanmıştır (40). Bu sonuçlar bu çalışma ile benzerlik göstermektedir.

Sonuç olarak bu çalışmada anormal yeme davranışı görülme sıklığı ve YTT puanı, hafif şişman ve obez bireylerde daha yüksek bulunmuştur. Bu çalışmanın sinırlılığı örneklem sayısının az olmasıdır. Zayıf bireylerin bulunduğu grupta da yeterli katılım sağlanarak, dört farklı BKİ grubunu dahil ederek daha kapsamlı çalışmalar yapılması daha uygun olacaktır. Aynı zamanda obez bireylerde anormalyemedavranışı diğer gruplara göre daha fazla görülebileceğinden, içinde doktor, diyetisyen ve psikoloğun da bulunacağı interdisipliner bir yaklaşım modeli örnek alınmalı ve bireyler bu doğrultuda tedavi edilmelidir. Sedanter yaşam ve yetersiz uyku da obezitenin nedenleri arasında gösterildiğinden, bireyin sağlıklı yaşam tarzı alışkanlıkları kazanmasına yardımcı olunmalıdır. Sağlıklı yaşam tarzı alışkanlıklarının kazanılmasında hedefler, sürdürülebilirlik de göz önünde bulundurularak belirlenmelidir.

Yazarlık katkısı - Author contributions: Çalışmanın tasarımı: NÖ, EAY; Çalı̧̧ma verilerinin elde edilmesi: NÖ; Verilerin analiz edilmesi: NÖ; Makale taslağının oluşturulması: NÖ, AAP; Iç̧erik için eleştirel gözden geçirme: NÖ, AAP, HGÖ; Yayınlanacak versiyonun son onayı: NÖ, AAP, EAY, HGÖ. - Study design: NÖ, EAY; Data collection: NÖ; Data analysis: NÖ; Draft preparation: NÖ, AAP; Critical review for content: NÖ, AAP, HGÖ; Final approval of the version to be published: NÖ, AAP, EAY, HGÖ..

Etik Kurul Onayı - Ethics approval: Hacettepe Üniversitesi Girişimsel Olmayan Klinik Araştırmalar Etik Kurulu'nun 10.05.2016 tarihli ve GO 16/294 sayll onayı alınmıştır. - The approval of Hacettepe University Non-Interventional Clinical Research Ethics Committee dated 10.05.2016 and numbered GO 16/294 was obtained.

Çıkar çatışması - Conflict of interest: Yazarlar çıkar çatışması olmadığını beyan ederler. - The authors declare that they have no conflict of interest.

\section{KAYNAKLAR}

1. T.C. Sağlık Bakanlığı, Sağlıklı Beslenme ve Hareketli Hayat Dairesi Başkanlığı, Obezite nedir. 2021. Erişim: https://hsgm.saglik.gov.tr/tr/obezite/obezite-nedir.html. Erişim tarihi: 11.08.2021.

2. World Health Organization, Obesity and Overweight. 2021. Available at: https://www.who.int/news-room/factsheets/detail/obesity-and-overweight. Accessed August 11, 2021.

3. T.C. Sağllk Bakanlığı, Türkiye Beslenme ve Sağlık Araştırması. Ankara; 2019. 440 sf.

4. Mangum BP, Mangum TL. Gene-environment interactions and the genetic epidemiology of obesity: correlates for preventative medicine. J Obes Metab Disord. 2018;1(1):25-8.

5. Romieu I, Dossus L, Barquera S, Blottiere HM, Franks PW, Gunter M, et al. Energy balance and obesity: 
what are the main drivers?. Cancer Causes Control. 2017;28(3):247-58.

6. Baysal A. Beslenme. 12. Baskı. Ankara: Hatiboğlu Yayınları; 2009. Şişmanlık; s. 529-533.

7. Silverstone S, Teatum J. Technology: The problem or the solution to childhood obesity. American Journal of Business Education. 2011;4(1):37-60.

8. Prentice AM. Early influences on human energy regulation: thrifty genotypes and thrifty phenotypes. Physiol Behav. 2005;86(5):640-5.

9. Wu Y, Zhai L, Zhang D. Sleep duration and obesity among adults: a meta-analysis of prospective studies. Sleep Medicine. 2014;15(12):1431-596.

10. Kuzbicka K, Rachon D. Bad eating habits as the main cause of obesity among children. Pediatr Endocrinol Diabetes Metab. 2013;19(3):106-10.

11. Adriaanse MA, de Ridder DT, Evers C. Emotional eating: eating when emotional or emotional about eating? Psychol Health. 2011;26(1):23-39.

12. Cardi V, Leppanen J, Treasure J. The effects of negative and positive mood induction on eating behaviour: a meta-analysis of laboratory studies in the healthy population and eating and weight disorders. Neurosci Biobehav Rev. 2015;57:299-309.

13. Bekker MH, van de Meerendonk C, Mollerus J. Effects of negative mood induction and impulsivity on selfperceived emotional eating. Int J Eat Disord. 2004;36:4619.

14. Dos Santos Alvarenga M, Baeza Scagliusi F, Tucunduva Philippi S. Comparison of eating attitudes among university students from the five Brazilian regions. Cienc. Saude Coletiva. 2012;17(2):435-44.

15. Kadıoğlu M, Ergün A. Üniversite öğrencilerinin yeme tutumu, öz-etkililik ve etkileyen faktörler. MÜSBED. 2015;5(2):96-104.

16. Pekcan G. Beslenme Durumunun Saptanması, Ankara: T.C. Sağlık Bakanlığı Temel Sağlık Hizmetleri Genel Müdürlüğü Beslenme ve Fiziksel Aktiviteler Daire Başkanlığı; 2008.

17. Savaşır I, Erol N. Yeme tutum testi: Anoreksiya nervoza belirtileri indeksi. Psikoloji Dergisi. 1989;7:19-25.

18. Garner DM, Garfinkel PE. The Eating Attitudes Test: An index of the symptoms of anorexia nervosa. Psychol Med. 1979;9(2):273-9.

19. IBM Corp. Released 2013. IBM SPSS Statistics for Windows, Version 22.0. Armonk, NY: IBM Corp.

20. Endalifer ML, Diress G. Epidemiology, predisposing factors, biomarkers, and prevention mechanism of obesity: A systematic review. J Obes. 2020;2020:6134362.

21. Choi E, Cho HN, Seo DH, Park B, Park S, Cho J, et al. Socioeconomic inequalities in obesity among Korean women aged 19-79 years: the 2016 Korean Study of
Women's Health-Related Issues. Epidemiol Health. 2019;41:e2019005.

22. Hosseinpanah F, Mirbolouk M, Mossadeghkhah A, Barzin M, Serahati S, Delshad $\mathrm{H}$, et al. Incidence and potential risk factors of obesity among Tehranian adults. Prev Med. 2016;82:99-104.

23. Nazlıcan E, Demirhindi H, Akbaba M. Adana İli Solaklı ve Karataş Merkez Sağlık Ocağı Bölgesinde yaşayan 20-64 yaş arası kadınlarda obezite ve ilişkili risk faktörlerinin incelenmesi. Düzce Üniversitesi Sağlık Bilimleri Enstitüsü Dergisi. 2011;1(2):5-12.

24. Boing AF, Subramanian SV. The influence of area-level education on body mass index, waist circumference and obesity according to gender. Int J Public Health. 2015;60:727-36.

25. Nazli R, Akhtar T, Lutfullah G, Khan MA, Lutfullah G, Haider J. Prevalence of obesity and associated risk factor in a female population of rural Peshawar-Pakistan. Khyber Medical University Journal. 2015;7(1):19-24.

26. Rachmi CN, Li M, Baur LA. Overweight and obesity in Indonesia: prevalence and risk factors-a literature review. Public Health. 2017;147:20-9.

27. Mata J, Frank R, Hertwig R. Higher body mass index, less exercise, but healthier eating in married adults: Nine representative surveys across Europe. Soc Sci Med. 2015;138:119-27.

28. Erem C. Prevalence of Overweight and Obesity In Turkey. IJC Metabolic \& Endocrine. 2015;(8):38-41.

29. Nikooyeh B, Abdollahi Z, Salehi F, Nourisaeidlou S, Hajifaraji M, Zahedirad M, et al. Prevalence of obesity and overweight and its associated factors in urban adults from West Azerbaijan, Iran: the National Food and Nutritional Surveillance Program (NFNSP). Nutrition and Food Sciences Research. 2016;3(2):21-6.

30. Bayram S, Köseler E, Kızıltan G, Ok MA, Yeşil E, Köse B, ve ark. Effects of reproductive and sociodemographic factors on obesity in Turkish women: a pilot study. Progress in Nutrition. 2019;21(1):77-85.

31. Ogilvie RP, Bazzano L, Gustat J, Harville E, Patel SR. Sleep duration and measures of obesity in a Biracial Cohort: The Bogalusa Heart Study. In D60. Sleep Patterns In Diverse Populations. 2018; (pp. A7289-A7289). American Thoracic Society.

32. Theorell-Haglöw J, Lindberg E. Sleep duration and obesity in adults: what are the connections? Current Obesity Reports. 2016;5(3):333-43.

33. Xiao Q, Arem H, Moore SC, Hollenbeck AR, Matthews CE. A large prospective investigation of sleep duration, weight change, and obesity in the NIH-AARP Diet and Health Study cohort. American Journal of Epidemiology. 2013;178(11):1600-10.

34. Eker İ. Güngören Toplum Sağlığı Merkezi Sağlıklı 
Beslenmeve Obezite Polikliniğine başvuran yetişkin obez kadınların beslenme durumlarının değerlendirilmesi [Bilim uzmanlığı tezi]. Okan Üniversitesi, İstanbul; 2017.

35. Padem Z. Farklı beden kütle indeksleri olan hipertansiyonlu hastaların beslenme durumlarının ve bazı biyokimyasal bulgularının değerlendirilmesi [Bilim uzmanlığı tezi]. Hacettepe Üniversitesi, Ankara; 2010.

36. Sağlam Z. Yetişkin bireylerde obezitenin depresyon, benlik saygısı, yeme tutumu ve beslenme durumu üzerine etkisi [Bilim uzmanlığı tezi]. Hacettepe Üniversitesi, Ankara; 2018.

37. Saral Dicle Ş. Investigation of eating attitudes and behaviors of employees of a bank in Istanbul With Eat-
40 [Bilim uzmanlığı tezi]. Yeditepe University, Istanbul; 2018.

38. Köse G, Tayfur M. BMI, physical activity, sleep quality, eating attitudes, emotions: which one is affected by mindful eating? Progress in Nutrition. 2021;23(1):e2021002.

39. Arslan, M. Aydemir, İ. Relationship between emotional appetite, eating attitudes, sleep quality, and body mass index in healthcare workers: A multi-centre study. Psychiatry Clin. Psychopharmacol. 2019;29:346-53.

40. Eladawi N, Helal R, Niazy NA, Abdelsalam S. Prevalence and associated factors of eating disorders in weight management centers in Tanta, Egypt. Chin Med J. 2018;131(1):50-5. 